\title{
GENETYCZNE UWARUNKOWANIA RELIGII W UJECIU RADYKALNEJ SOCJOBIOLOGII
}

\author{
SOCJOBIOLOGIA JAKO NAUKA
}

Wiek XIX przyniósł trzy istotne próby odrzucenia religii na podstawie przesłanek nauki. Dostarczył ich zainicjowany przez Comte'a pozytywizm, materializm marksistowski i psychoanaliza freudowska. Z perspektywy stulecia uległy zasadniczej rewizji pierwotne wersje argumentów wytaczanych przeciw religii. We współczesnej retoryce humanistycznej krytykuje się nauki przyrodnicze w takim samym stylu, w jakim zafascynowany nauką Comte krytykował religię. Współczesny neomarksizm przyznaje, iż nie tylko religia może stanowić opium ludu, lecz również narzucany administracyjnie ateizm może okazać się opium dla funkcjonariuszy. Nam współcześni kontynuatorzy Freuda przyznają, iż nie tylko dylematy religijne, lecz również rozterki agnostyków $\mathrm{i}$ ateistów mogą prowadzić do nerwic. $\mathrm{Z}$ upływem czasu uległy więc istotnemu złagodzeniu tezy, które w początkowym radykalnym sformułowaniu zdawały się definitywnie przesądzać koniec religii. Istnieją podstawy, by sądzić, że prawidłowość taka występuje również w przypadku socjobiologicznej krytyki religii. Dlatego też w artykule tym chcę rozgraniczyć między radykalną krytyką religii, proponowaną przez E. O. Wilsona, M. Ruse'a i C. J. Lumsdena, a tymi ujęciami socjobiologii, w których troska o racjonalne uzasadnienie proponowanych tłumaczeń dominuje nad dążeniem do łatwych ekstrapolacji i uogólnień.

W najbardziej znanym ujęciu, przedstawionym przez Wilsona na kartach On Human Nature ${ }^{1}$ religia traktowana jest jako uwarunkowany genetycznie element kultury, ułatwiający gatunkowi ludzkiemu dostosowanie w ewolucyjnej walce o byt. Społeczność ludzka funkcjonuje sprawnie dzięki podzielanemu systemowi wierzeń. Nie ma jednak powodów, by wierzenia te uważać za obiektywnie uzasadnione lub prawdziwe. Przeciwnie, stanowią one element 1988.

${ }^{1}$ Harvard University Press 1978; polski przekład B. Szackiej: O naturze ludzkiej. Warszawa 
składowy tworzonej przez człowieka niezmiennie mitologii, która ułatwia przetrwanie genom charakterystycznym dla naszego gatunku. Dlatego twierdzenia religii, podobnie jak zasady etyki, należy uważać tylko za determinowane przez geny „złudzenia podzielane przez rasę ludzką"2. Konsekwentnie bogactwo treści przeżycia religijnego można zredukować do dwóch czynników: korzyści genetycznej i zmiany ewolucyjnej ${ }^{3}$.

Eseistyczny styl i metaforyczny język Wilsona pod wieloma względami przypomina deklaracje, jakie do rozważań Dialektyki przyrody wprowadzał Engels pod wpływem lektury popularyzatorskich prac Haeckla. Kiedy jednak u Engelsa triumfująca nauka zadawała ostateczny cios religii, u Wilsona brak równie optymistycznego epilogu. $\mathrm{Z}$ jednej strony bowiem sama nauka i korespondujący z nią „materializm naukowy” stanowi również jedynie produkt mitotwórczej działalności człowieka. $\mathrm{Z}$ drugiej strony uwarunkowana genetycznie religia ma stanowić „niezbywalną część natury ludzkiej”4. Skutkiem tego utrzymany w Engelsowskiej konwencji obraz konfliktu religii i nauki nie kończy się happy endem. Chociaż bowiem materializm naukowy „punkt po punkcie odnosi zwycięstwo nad tradycyjną religią we wszystkich obszarach konfliktu” i chociaż „nauka kolejno obala jedną po drugiej mityczne opowieści” teologów, to jednak ,teologia wycofuje się w kierunku ostatniej reduty, z której nigdy nie będzie można jej wyprzeć"5. Redutę tę ma stanowić idea BogaStwórcy, która pozostaje niezmiennie atrakcyjna nawet dla sympatyków ewolucji i tym samym może prowadzić do przypływów nowej popularności religii, jeśli przedstawiciele materializmu naukowego nie wykażą dostatecznej czujności ${ }^{6}$.

Mocne i pozbawione uzasadnienia tezy Wilsona są przyjmowane ze sceptycyzmem nawet w kręgach przedstawicieli socjobiologii. Bliski tej dziedzinie badań Ralph W. Burhoe ogranicza się np. do sformułowania znacznie ostrożniejszej tezy, iż idea Boga została zakodowana biologicznie w ludzkim genotypie i potrzeba nam nowej „,naukowej teologii”, która podda krytycznej ocenie biologiczne i czysto racjonalne elementy wiary religijnej. Teologia taka, zdaniem autora Toward a Scientific Theology, zakończy okres zimnej wojny między nauką i religią ${ }^{7}$, doprowadzi do nowej integracji wartości naukowych i religijnych z kulturą humanistyczną oraz — dzięki wykorzystaniu dorobku socjobiologii — wypracuje nową koncepcję natury ludzkiej jako wyniku symbiozy genów oraz informacji kulturowej ${ }^{8}$. W tekstach Burchoe'a pojawia się często nieuzasadniony religijny enuzjazm, którego status zdaje się nie różnić od entu-

\footnotetext{
${ }^{2}$ M. Ruse, E. O. Wils o n, The Evolution of Ethics, „New Scientist” 17 : 1985 s. 51.

${ }^{3}$ O naturze..., s. 212.

${ }^{4}$ Tamże, s. 209.

${ }^{5}$ Tamże, s. 232.

${ }^{6}$ Tamże.

${ }^{7}$ R. W. B ur hoe, War, Peace, and Religion's Biocultural Evolution, „Zygon” 21 : 1986 s. 466.

${ }^{8}$ Tamże, s. 439.
} 
zjastycznej krytyki religii, proponowanej przez Wilsona. Trudno jest np. przywiązywać większą wagę do tekstów, w których autor Science and Human Values in the $21^{\text {st }}$ Century zapowiada, iż następne stulecie wyda misjonarzy uniwersalnej religii, którzy rozwiną nową syntezę nauki i wiary w tym samym stylu, w jakim wczesne chrześcijaństwo połączyło prawdę Ewangelii z tradycją myśli greckiej.

Podobne prognozy pozostają znowu wyrazem osobistych odczuć autora; trzeba je jednak dostrzec, aby nie identyfikować socjobiologicznych ocen religii z eseistyczną retoryką Wilsona. Uznając istnienie zasadniczych różnic między przedstawicielami omawianego nurtu, Philip Kitcher w Vaulting Ambition rozróżnia między „ciasną (narrow) socjobiologią”, w której formułuje się mocne i nieuzasadnione tezy antropologiczne ${ }^{9}$, a otwartą socjobiologią, w której przy pomocy badań empirycznych określa się biologiczne uwarunkowania zachowań społecznych. Ta pierwsza, z racji szerokiego oddźwięku towarzyszącego jej mocnym tezom, bywa nazywana ironicznie ,pop-socjobiologią"10; druga - mimo braku obrazoburczych deklaracji - posiada sięgającą lat czterdziestych tradycję badawczą. Sam termin „socjobiologia” został wprowadzony w 1946 r. przez Johna P. Scotta na oznaczenie dyscypliny nazwanej również „,biosocjologią”, ,,ekologią behawioralną” lub „,socjologią zwierząt”. Merytoryczna prawomocność podobnej dyscypliny nie ulega wątpliwości, gdyż zarówno zjawiska społeczne, jak i dorobek kulturowy posiadają niewątpliwe podłoże biologiczne, które w pewnym stopniu wpływa na naturę wspomnianych zjawisk. Kontrowersje pojawiają się natomiast wtedy, gdy charakter tego wpływu usiłuje się określić apriorycznie wybierając najprostsze z dopuszczalnych teoretycznie możliwości.

Wyjątkowo emocjonalne dyskusje wokół socjobiologii rozwinęły się po opublikowaniu w 1975 r. przez Wilsona pracy Sociobiology: The New Synthesis, w której ostatnim rozdziale fenomen ludzkiej kultury zostal zinterpretowany w kategoriach biologii. Metodologiczne przesłanki dla podobnej ekstrapolacji sformułował Wilson już cztery lata wcześniej, gdy w pracy The Insect Societies umieścił rozdzial „Perspektywa zunifikowanej socjobiologii”. Właśnie kontrowersyjna unifikacja, w której zaciera się istotne różnice między światem człowieka i światem zwierząt niższych, zadecydowała o tym, iż Wilsonowską wizję natury ludzkiej poddali ostrej krytyce antropologowie i historycy nauki, metodolodzy, biologowie i przedstawiciele nauk społecznych. Już w 1977 r. podczas zebrania American Sociological Association zgłoszono propozycję potępienia socjobiologii jako dyscypliny pseudonaukowej. Wniosek ten oddalono, uznając iż nauki należy bronić przy pomocy merytorycznych argumentów nie zaś administracyjnych potępień. Równocześnie jednak zwrócono uwa-

${ }^{9}$ Tak pojętą dyscyplinę określam w niniejszym artykule mianem „radykalnej socjobiologii”.

10 Zob. np. S. J. Gould, An Urchin in the Storm, New York 1987. 
gę na bezpodstawność socjobiologicznych uogólnień oraz na ich niepokojące implikacje etyczne. Koncentrując uwagę na tych ostatnich, grono dawnych kolegów Wilsona z Uniwersytetu Harvarda zainicjowało spektakularny protest sygnowany przez tzw. „Grupę nauki dla ludu badającą socjobiologię”. Członkowie grupy zarzucili Wilsonowi głoszenie determinizmu biologicznego, w którym przez odwołanie do rzekomych zasad genetyki stwarza się podstawy do obrony przekonań rasistowskich bliskich faszystowskiej koncepcji człowieka i społeczeństwa oraz uprawia apologetykę agresji, ksenofobii czy erotomanii, usprawiedliwiając wygodne zachowania uwarunkowaniami genetycznymi.

Emocjonalne oskarżenia i argumenty ad personam dominowały początkowo w krytyce Wilsonowskich tez. Ich zirytowani autorzy podkreślali, iż posiadanie doktoratu z zoologii nie upoważnia do zabierania głosu na temat istoty ludzkiego altruizmu, zaś literacka swada nie może zastąpić wynikania logicznego. Sam Wilson zdawał się dokładać wysiłków, by podobnym zarzutom nadać maksymalną wiarogodność. Żenujące wrażenie robią jego teksty, w których na przekór elementarnym zasadom logiki pisze on o „trzeciej alternatywie"11, Whiteheadowi przypisuje wyprowadzanie wniosku „o obecności Boga z właściwości struktury atomu"12, a obrazoburczą, własną koncepcję matematyki przedstawia zaraz po wyjaśnieniu, iż jest matematycznym półanalfabetą ${ }^{13}$.

Niezależnie od głębokich rewizji, jakim pod wpływem krytyk Wilson poddał swe poglądy, oraz niezależnie od wewnętrznych niespójności, jakie występują niezmiennie w interpretacjach radykalnej socjobiologii, debaty nad biologicznymi uwarunkowaniami ludzkiej kultury podejmują podstawowe kwestie filozofii. Prowadzone polemiki ukazują perspektywę nowych ujęć problemu racjonalności wiedzy, natury człowieka, podstaw norm moralnych czy ostatecznych uwarunkowań idei Boga. Mimo iż kierunkiem filozoficznym bliskim deklaracjom radykalnej socjobiologii pozostaje pozytywizm Comte'a i empiryzm Hume'a, podejmowane są również próby reinterpretacji jej twierdzeń przy pomocy filozoficznych kategorii wypracowanych przez Kanta, Hegla a nawet Platona ${ }^{14}$. Różnice te świadczą, iż związki naszej genetyki z kulturą mogą mieć interpretacje zasadniczo odmienne od tej, którą zaproponował Wilson. Odnosząc się sceptycznie do merytorycznych podstaw socjobiologii, A. R. Peacocke twierdzi wręcz, że nawet gdyby okazała się ona prawdziwą, nie stanowiłaby zagrożenia dla religijnej wiary w Boga ${ }^{15}$. To głębokie zróżnicowanie filozoficznych komentarzy wskazuje na celowość dokładniejszego podjęcia kwestii socjobiologicznej interpretacji istoty religii. Podejmując tę problema-

${ }^{11}$ Introduction: What is Sociobiology?, [w:] Sociobiology and Human Nature, ed. M. S. G r e gory, A. Silvers, D. Sutch, London 1978, s. 4.

12 O naturze..., s. 211.

13 Biophilia: The Human Bond with Other Species, Harvard University Press 1984, s. 65.

${ }^{14}$ Zob. różnorodne interpretacje filozoficzne socjobiologii, zawarte w pracy: Sociobiology and Epistemology, ed. J. H. Fet zer, Reide l, Dordrecht 1985, s. 7.

${ }^{15} \mathrm{~A}$. P e a cock e, God and the New Biology, London 1986, s. XX. 
tykę, najpierw poddam analizie poprawność Wilsonowskiego obrazu religii; następnie zaś zajmę się prawomocnością redukcjonizmu biologicznego, w którym usiłuje się kwestionować istnienie transcendentnego korelatu twierdzeń religijnych.

\section{EWOLUCYJNE ASPEKTY RELIGII}

Możliwość genetycznego uwarunkowania wierzeń religijnych rozważano już wcześniej także poza nurtem socjobiologii. M. in. dopuszczał ją Jacques Monod zastanawiając się nad powszechnością wierzeń religijnych. Kiedy jednak w interpretacji Monoda podstawową rolę miała odgrywać przypadkowa mutacja wpisująca ideę Boga w genotyp kosmicznych Syzyfów, u sympatyków Wilsona otrzymujemy rozwiniętą interpretację ewolucyjną, w której zarówno przekonania religijne, jak i altruizm etyczny służą interesom genów w walce o byt. Interpretacja taka zakłada filozoficzny monizm, jak i ontologiczny redukcjonizm. Całe bogactwo świata ludzkiej kultury, z charakterystyczną dla naszego gatunku moralnością i zespołem wierzeń, zostaje potraktowane jako produkt ulegających ewolucyjnym zmianom oddziaływań między genotypem człowieka a warunkami środowiska. Ten podstawowy aksjomat ma tłumaczyć zarówno wielość istniejących wierzeń religijnych, jak i ich ewolucję w czasie.

Przeciwstawiając się oskarżeniom o determinizm biologiczny. Wilson podkreśla, iż nie twierdzi, jakoby cała nasza kultura, w tym również teorie naukowe, stanowiła wynik determinant zakodowanych w genotypie. Ujęcie takie dostarczałoby podstaw do oskarżeń o fatalizm, gdyż kod genetyczny naszego gatunku realizowałby w czasie plany niezależne od jakichkolwiek uwarunkowań zewnętrznych. Antyfatalistyczne deklaracje socjobiologów nie upoważniają jednak, według tej grupy badaczy, do poszukiwania czynników pozagenetycznych, które wpływają na postać i zawartość treściową naszej kultury. Przeciwstawiając się kategorycznie interpretacjom, w których usiłowano by uzasadniać reguły ludzkiej moralności z pominięciem ich genetycznego podłoża, Ruse twierdzi kategorycznie, iż interpretacje takie byłyby redundantne z punktu widzenia socjobiologii. Socjobiologiczny darwinista utrzymuje bowiem, iż jego „teoria dostarcza totalnej analizy naszych odczuć moralnych. Nie potrzeba niczego więcej. ... Trzeba definitywnie wykluczyć obiektywistyczne podejście w etyce" 16 .

Ostatnia z przytoczonych deklaracji ukazuje poznawczy totalizm socjobiologii. Dyscyplina ta, przynajmniej w swej radykalnej wersji, definitywnie wyklucza możliwość wypracowania niezależnych racjonalnych uzasadnień dla tez warunkowanych genetycznie. W sytuacji takiej prima facie niekontrowersyjne

${ }^{16}$ Taking Darwin Seriously: A Naturalistic Approach to Philosophy, London 1987, s. 254. 
wypowiedzi o wzajemnym oddziaływaniu na siebie czynników genetycznych i środowiskowych uzyskują specyficzny sens, z którego wynika definitywny prymat genów w interakcjach genetyczno-kulturowych. Zarówno postać jak i kierunek tych interakcji są pochodną naszego genotypu. Genotyp określa tzw. reguły epigenetyczne, które narzucają nam zestaw zachowań i przekonań ułatwiających przetrwanie w określonych warunkach ewolucyjnego rozwoju. Ze zmianą tych warunków, bądź to w wyniku ewolucji fizycznej bądź też rozwoju kulturowego, ulegają modyfikacji reguły epigenetyczne. W konsekwencji tych zmian „religie, podobnie jak pozostałe ludzkie instytucje, ewoluują w kierunku korzystnym dla ich wyznawców"17.

Na kartach Promethean Fire Wilson i Lumsden przyznają, iż jakiś wiariant socjobiologii dałby się pogodzić z teistyczną interpretacją ewolucji. Wystarczyłoby np. przyjąć, iż w procesie oddziaływania genów i środowiska jest realizowany określony przez Stwórcę program ortogenezy ${ }^{18}$. Obaj autorzy kategorycznie odrzucają taką wizję. Nie starają się przy tym merytorycznie uzasadniać swej decyzji, lecz tylko ograniczają się do konstatacji: „Przyjmujemy inny pogląd. Wierzymy, iż sekret nagłej emergencji świata myśli polega na włączeniu mechanizmu, który zarówno podlega prawom fizycznym, jak i przysługuje tylko gatunkowi ludzkiemu... Wierzymy, że ewolucyjne współoddziaływanie genów i kultury, bez jakiejkolwiek zewnętrznej pomocy, stworzyło człowieka; natomiast sposób funkcjonowania tego mechanizmu można określić przez kombinację technik wziętych z nauk przyrodniczych i społecznych" ${ }^{19}$.

Autorzy przytoczonej deklaracji obiektywnie przyznają, iż stanowi ona jedynie przedmiot ich wiary. Wiara ta ma dostarczać prostej i zunifikowanej wizji świata, w której nie pojawia się nieciągłość między światem przyrody i światem kultury ani też nie ma potrzeby odwoływania się do czynników pozanaturalnych. Przy ocenie stopnia jej uzasadnienia podstawowe pozostaje pytanie: Czy można racjonalnie wykazać, iż istotnym składnikiem wszystkich wierzeń religijnych pozostaje ich przydatność w ewolucyjnej walce o byt? Przedstawiciele radykalnej socjobiologii odpowiadają twierdząco na to pytanie. Moja odpowiedź jest zdecydowanie przecząca. W próbie uzasadnienia własnego stanowiska najpierw zwrócę uwagę na niedopuszczalne uproszczenia w Wilsonowskim obrazie religii, następnie zaś zajmę się semantyczną wieloznacznością wyrażenia „przydatność ewolucyjna”.

We wprowadzeniu do polskiego wydania On Human Nature Barbara Szacka słusznie podkreśla, iż Wilson występuje w swych publikacjach nie jako beznamiętny badacz, ale jako prorok przekazujący swe posłannictwo szerokim kręgom społecznym ${ }^{20}$. Znamienne cechy perspektywy proroka pojawiają się

\footnotetext{
$17 O$ naturze, s. 215.

18 The Promethean Fire, Harvard University Press 1983, s. 19.

19 Tamże, s. 20.

20 Stowo wstepne, [w:] O naturze..., s. 14.
} 
w socjobiologii wówczas, gdy z rozległego zbioru dostępnych danych wybierane są selektywnie tylko te, które korespondują z proponowaną wizją, natomiast niemniej reprezentatywne elementy przeciwstawne są systematycznie ignorowane. Prowadzi to do jednostronnych, nierzadko wręcz karykaturalnych, zniekształceń w ukazywanym obrazie religii. Kategoria „przydatności ewolucyjnej” pełni w konstruowaniu tego obrazu podobną rolę, jaką kategoria „interpretacji klasowej" odgrywała w socrealistycznych komentarzach do muzyki Mozarta lub dramatów Szekspira. W obu przypadkach proponowane interpretacje mogą okazać się sugestywne dla tych, którzy wcześniej uwierzyli w suponowane przez nie aksjomaty. Dla krytyka, który bardziej ceni racjonalne uzasadnienia niż retoryczną sugestywność, podstawowym problemem pozostanie kwestia: Jak dowieść prawdziwości aksjomatów, które proponując radykalnie nowy sens ludzkiej kultury, wymagają irracjonalnej wiary opartej jedynie na psychologicznej atrakcyjności nowej wizji?

O tym, jak bardzo arbitralna jest ta wizja, świadczy socjobiologiczna charakterystyka wierzeń religijnych. W tekstach Wilsona wiara religijna jawi się jako synonim ideologii, światopoglądu czy przesądów. Jednym tchem wymienia on chrześcijaństwo i maniakalną astronomię Velikovsky'ego, astrologię i leninizm, mistykę Wschodu i maoizm ${ }^{21}$. Podejście takie nie jest bynajmniej ubocznym produktem swady literackiej, gdyż znajdujemy je w wielu innych tekstach zwolenników radykalnej socjobiologii. Dla przykładu, Michael Ruse wymienia katolicyzm obok antynaukowej scjentologii Hubbarda, za reprezentatywny dla myśli chrześcijańskiej uważa ciasny fundamentalizm interpretujący dosłownie Pismo święte zaś w misji Chrystusa jako szczególnie doniosłe uważa to, „iż jeden dobrze znany Nazareńczyk” posiadał zdolność chodzenia po wodzie 22 .

Dla integralności obrazu warto zaznaczyć, iż podobna nonszalancja występuje w socjobiologicznej charakterystyce nauki jako elementu kulturowego, który ułatwia genom ewolucyjną walkę o przetrwanie. W proponowanym ujęciu nauki można dowiedzieć się, iż geometrie nie-euklidesowe powstały dopiero w XIX wieku, bo Australopitek nie potrzebowal piątego postulatu, zasada nieznaczoności Heisenberga jest jedynie pragmatycznym urządzeniem do unikania niewygodnych pytań, natomiast metamatematycznemu twierdzeniu Gödla niezasłużony rozgłos nadali Platonicy i teiści ${ }^{23}$. Po podobnych radykalnych reinterpretacjach, w których całkowicie ignoruje się problem obiektywnej prawdziwości twierdzeń nauki, można już bronić tezy o ewolucyjnej użyteczności refleksji teoretycznej. Ruse czyni to argumentując: „te istoty ludzkie, które wierzyły, że $2+2=5$ lub że ogień jest przyczyną orgazmu, ... zostały

${ }^{21}$ O naturze..., s. 211, 224 n.

${ }_{22}^{2}$ M. Ru se, Taking Darwin Seriously: A Naturalistic Approach to Philosophy, London 1987, s. $175,148,178,176$.

${ }_{23}$ Tamże, s. 171, 157, 170. 
starte w walce o byt" ${ }^{\prime 24}$. W perspektywie tej ignoruje się znane $\mathrm{z}$ historii nauki przykłady, kiedy to obrońcy niestandardowych idei bronili swych przekonań narażając zarówno własne życie, jak i ustabilizowaną egzystencję rodziny, na przekór elementarnym zasadom walki o byt. Pomija się również to, iż gdyby najwyższym celem nauki miało być ułatwianie ewolucyjnego przetrwania jej przedstawicielom, wówczas - jak to słusznie podkreśla D. L. Hull ${ }^{25}$ — przekazywanie wiedzy ewolucyjnym rywalom stawałoby się aktem samozagłady. Konsekwentne zastosowanie w praktyce dydaktycznej tezy o ewolucyjnej roli nauki wymagałoby przekazywania innych zasad nauki osobom związanym rodzinną czy plemienną wspólnotą genów, innych zaś nosicielom genów konkurujących w walce o byt. Przyjęcie takiej właśnie zasady nie tylko stanowiłoby przejaw prostej konsekwencji logicznej, lecz również upodobniłoby socjobiologiczną koncepcję nauki do osławionej koncepcji klasowego charakteru nauki wykorzystywanej w konfliktach interesów społecznych.

Mimo iż Wilson twierdzi, iż formułując tezę o „biologicznych korzyściach” płynących z życia religijnego poddał „dokładniejszej” analizie „najbardziej wzniosłe formy praktyk religijnych" ${ }^{26}$, niemal każde z jego „dokładniejszych” uogólnień można uznać za uproszczone, dowolne lub nie uwzględniające znanych kontrprzypadków. Tak np. twierdzi on, iż religia tworzy u wyznawców „krzepiące poczucie tożsamości” sakralizując ich samoidentyczność i włączając we wspólnotę grupy, która głosi swoją potęgę ${ }^{27}$. Być może charakterystyka taka byłaby poprawna w odniesieniu do zadowolonych z siebie Pelagian, ale trudno ją odnosić do eremitów wybierających samotność pustyni, reformatorów rozczarowanych wspólnotowym status quo czy naśladowców Mertona, wybierających wspólnotę życia zakonnego, nawet jeśli dostarcza im ona przede wszystkim rozterek i codziennych niepokojów ducha. Ani Paweł Apostoł ani Dietrich Bonhoeffer lub samotnie ginący misjonarze nie odnaleźli na szlaku wiary krzepiącego odczucia wspólnotowej potęgi, lecz odnaleźli prawdę, iż doświadczenie ludzkiej słabości może stanowić dziedzinę odkrycia łaski, która definitywnie wymyka się uporządkowanym schematom, kalkulacjom czy ewolucyjnym zyskom. Programowe ignorowanie poziomu łaski i całego bogactwa jej przejawów nie może dać adekwatnego obrazu wierzeń religijnych.

Oczywiste zniekształcenia obrazu pojawiają się wielokrotnie, gdy socjobiologowie wprowadzają aksjomatycznie tezy nie zadając sobie trudu ich uzasadnienia. Tak np. Wilson twierdzi, iż „źródło religijnego altruizmu” znajduje się w słowach rozesłania uczniów przez Jezusa $(M k 16,15 n)$. Trud głoszenia

24 Tamże, s. 189.

${ }^{25}$ The Herd as a Means, [w:] PSA 1980, ed. P. D. Asquith, R. N. Giere, East Lansing 1981 , s. 87.

${ }^{26} \mathrm{O}$ naturze..., s. 228. Oryginał angielski informuje: „The highest forms of religious practice, when examined more closely, can be seen to confer biological advantage" (On Human Nature, Harvard University Press 1978, s. 188).

${ }_{27}$ O naturze..., s. 228. 
Ewangelii zostaje zrekompensowany przez dominację nad tymi, którym niesie się zbawienie. Pozorny altruizm ma w istocie uwarunkowanie egoistyczne, ułatwiając supremację w biologicznej walce o byt ${ }^{28}$. Ponieważ sam kontekst rozesłania nie mówi niczego o altruizmie, powstaje pytanie, czy przy ocenie uwarunkowań altruizmu Ewangelii nie należałoby raczej poddać analizie tych tekstów, które odnoszą się wprost do omawianej tematyki, postulując postawę bezinteresownej służby, samozaparcia, miłości wykraczającej poza granice kulturowych konwenansów czy zdroworozsądkowych kalkulacji. Tymczasem Wilson ignoruje fakt, iż dobry Samarytanin nie szuka dla siebie jakichkolwiek korzyści płynących z altruistycznej pomocy pobitemu. Ignoruje on również te teksty, w których Jezus ucząc nowego przykazania miłości kategorycznie zakazuje szukania podobnych korzyści. Zakaz Chrystusa obejmuje nie tylko empirycznie obserwowalną sferę pragmatyki działania, lecz również dziedzinę myśli, motywacji i pragnień.

Aby socjobiologicznie zinterpretować podobne teksty, trzeba uciec się do „demistyfikacyjnej” tezy, która głosi, iż deklarowany altruizm Ewangelii jest w istocie ukrytym egoizmem. Wilson nie cofa się przed taką tezą i usiłuje przypisywać nieuświadomiony egoizm nawet Matce Teresie z Kalkuty, która służąc Chrystusowi ma uzyskiwać zarówno bezpieczny komfort psychiczny, jak i gwarancję osobistej nieśmiertelności ${ }^{29}$. Ostatnia teza świadczy wymownie o metodach badawczych radykalnej socjobiologii. W imię obrony aksjomatów zapewniających prostotę obrazu, wprowadza się w niej szokujące interpretacje faktów, których się nigdy nie badało. W polemikach filozofów nauki dużo miejsca poświęcano sporom o to, czy metody badawcze psychoanalizy można uważać za naukowe. Radykalna socjobiologia włącza się implicite w ten spór proponując zasadniczą liberalizację pojęcia metody naukowej. Po przyjęciu jej założeń, można — bez zadawania sobie trudu jakichkolwiek badań psychoanalitycznych - określić rzeczywiste motywy działań Matki Teresy, które w dodatku nie są nawet uświadamiane przez nią samą. Po przyjęciu aksjomatu o podstawowym interesie genów w ewolucji ludzkich społeczeństw, można dedukcyjnie „rozwiązywać” najbardziej skomplikowane kwestie bez podjęcia elementarnych badań empirycznych.

Podobne procedury metodologiczne są stosowane systematycznie w radykalnej socjobiologii. Dochodzi do nich wieloznaczność podstawowych terminów i konsekwentne powtarzanie błędu petionis principii w połączeniu $\mathrm{z}$ ignorowaniem niewygodnych faktów. Kiedy więc dowiadujemy się, iż „praktyki religijne wpływają na dobrobyt osobników i plemion" 30 , to podstawowym pytaniem pozostaje kwestia empirycznego sensu terminu „dobrobyt”. Z kontekstu wynika, iż należy rozumieć go bardzo szeroko. Przejawem dobrobytu jest

28 O naturze..., s. 206.

29 Tamże.

30 Tamże, s. 218. 
m. in. wielodzietność rodziny, która ma swe podłoże w tym, iż praktyki religijne poprzez system fizjologicznych regulatorów „konsekwentnie wspierają przetrwanie i prokreację wyznawców"31. Wilson nie wyjaśnia, czy zasadę tę należy odnosić również do celibatariuszów i nie wypowiada się na temat wspominanych w innym kontekście Shakersów, która to grupa religijna wyginęła po konsekwentnym wprowadzeniu powszechnego celibatu ${ }^{32}$.

Ten sam styl argumentacji znajdujemy w zapewnieniach o tym, iż „tradycyjne wierzenia religijne uległy erozji ... w wyniku rosnącej świadomości, iż wierzenia stanowią jedynie mechanizmy ułatwiające przetrwanie"33. Przy formułowaniu podobnej konstatacji naturalne jest oczekiwanie na odniesienie do danych empirycznych, które mogłyby uzasadnić tezę o „rosnącej świadomości" tego, iż religia stanowi je d y ni e mechanizm ewolucyjnego przetrwania. Tymczasem zamiast odsyłaczy do badań empirycznych znajdujemy u Wilsona tylko samozwrotne argumenty, z których wynika, iż tzw. „rosnąca świadomość" biologicznej użyteczności religii występuje głównie w świadomości sympatyków radykalnej socjobiologii. Do tej samej grupy „argumentów” należą zdroworozsądkowe konstatacje, iż „nader rzadko" spotyka się przejawy tolerancji religijnej ${ }^{34}$, natomiast uwarunkowane genetycznie zdolności do konsekracji i ślepego posłuszeństwa nader często generują masochistyczną praktykę totalnego zaufania działaczom lub instytucjom quasi-religijnym ${ }^{35}$.

Wśród prostych uogólnień uderzają powierzchowne analogie, w których akcentuje się podobieństwa między zgromadzeniami religijnymi a pochodem pierwszomajowym, ujmuje marksizm w kategoriach religijnych, wprowadza naiwne przeciwstawienia między naukowym a religijnym tłumaczeniem rzeczywistości: Ujęcie takie staje się bardziej zrozumiałe dopiero po zapoznaniu się $\mathrm{z}$ treścią przypisu, który zamyka rozdzial poświęcony religii ${ }^{36}$. Wilson informuje tam, iż swe poglądy na relację między religią i nauką ukształtował na podstawie sześciu artykułów, wśród których wymienia m. in. recenzję książki opublikowaną w New York Times oraz tekst Ch. Frieda Uniwersytet jako Kościót i partia. Po tym wyjaśnieniu staje się jasne, dlaczego w radykalnej socjobiologii nie znajdujemy zrozumienia istoty przeżyć religijnych. W konsekwencji, trudno spodziewać się, iż dyscyplina ta dostarczy racjonalnego wyjaśnienia genezy religii.

31 Tamże.

${ }^{32}$ Shakersi, pełna nazwa: Zjednoczony Kościót wierzacych $w$ drugie przyjście Chrystusa, wywodzili się z XVIII-wiecznych kwakrów, którzy twierdzili, iż Chrystus przyszedł na Ziemię po raz wtóry wcielony w osobę Matki Ann Lee. Żyjąc przekonaniem o spełnieniu się eschatologicznych zapowiedzi, wymagali oni rezygnacji z tradycyjnych form życia rodzinnego oraz przyjęcia celibatu. Przez pewien czas grupa rozwijała się dzięki nowyn konwersjom; w latach pięcdziesiątych liczyła ona jednak zaledwie kilkanaście osób.

${ }_{33}$ On Human Nature, s. 3; polskie wydanie: s. 29.

34 Tamże, s. 215.

35 Tamże, s. $225-227$.

36 O naturze..., s. $232 \mathrm{n}$. 
Przyjęcie aksjomatu, iż religia, podobnie jak moralność czy nauka, służy biologicznym interesom gatunku ludzkiego i ułatwia dostosowanie w ewolucyjnej walce o byt, okazuje się kontrowersyjne, z racji niejasnej treści operacyjnej terminu „dostosowanie” (resp. „interesu” lub jego semantycznych odpowiedników). Bardzo często w wypowiedziach o dostosowaniu ewolucyjnym uwikłane są albo tautologie albo circulus vitiosus. Dowiadujemy się wówczas np. że pterodaktyle wyginęły, bo nie były przystosowane zaś homo sapiens przetrwał dzięki doskonałemu przystosowaniu. Jak jednak określić w sposób wolny od błędnego koła wskaźniki tego przystosowania? Współczesne kontrowersje wokół tej problematyki odeszły daleko od sugestii klasycznego darwinizmu, w których sugerowano, iż np. stopień złożoności organów pozostaje obiektywnym wskaźnikiem ich ewolucyjnego dostosowania do złożoności warunków. Wśród wielu proponowanych obecnie ekscentrycznych koncepcji „dostosowania" można $\mathrm{m}$. in. znaleźć sugestie, aby za oznakę wyższego dostosowania uważać nawet te przejawy okaleczenia organizmów, które pozwalają imponować w walce o samicę stwarzając wrażenie, iż okaleczony osobnik jest w stanie nawiązać równorzędną walkę z nieokaleczonymi partnerami. Tej wysoce antropomorficznej koncepcji dostosowania broni m. in. A. Zahavi w swej teorii handicap selection ${ }^{37}$. Przy jej sceptycznej ocenie można zgodzić się z Richardem Dawkinsem, gdy pisze on, że gdyby teoria ta była prawdziwa, wówczas najwyższy stopień ewolucyjnego dostosowania należałoby przyznać fizycznie sprawnym osobnikom o jednej nodze lub jednym oku ${ }^{38}$.

Istniejące różnice zdań przy próbach określenia kryteriów ewolucyjnego dostosowania w walce o byt pozbawiają mocy argumentacyjnej podstawową tezę socjobiologii o ewolucyjnej przydatności religii. Łatwo przekonać się, iż w sugestywnych przykładach Wilsona i Ruse'a w różnym kontekście z tezą tą łączy się zasadniczo różne treści. Semantyczna rozmytość terminów pozwala socjobiologicznie wyjaśniać dowolny zestaw danych uważanych za reprezentatywne dla religii. Praktyka taka decyduje o niefalsyfikowalnym charakterze podstawowych aksjomatów przyjętych w socjobiologicznej krytyce religii. Brakowi temu można by niewątpliwie przeciwdziałać określając dziedzinę ewentualnych zjawisk, które zmuszałyby do odrzucenia tezy o biologicznych korzyściach płynących z wiary religijnej. Jak dotąd jednak w socjobiologii znacznie więcej miejsca poświęca się apologetyce przyjętych zasad niż trosce o ich falsyfikowalność. Apologetykę taką ułatwiają nieostre terminy podstawowe i metaforyczne sformułowania typu ,geny trzymają kulturę na smyczy”, „kultura wyskoczyła z genów", etc. Najbardziej precyzyjny wykład socjobiologii przedstawiony w Genes, Mind and Culture przy wykorzystaniu przez Wilsona i Lumsdena modeli matematycznych spotkał się też z najbardziej jednoznacz-

${ }^{37}$ Mate selection - a selection for handicap, „J. Theor. Biol.” 58 : 1975 s. 205.

${ }^{38}$ The Selfish Gene, New York 1976, s. 172. 
ną krytyką. Jej autorzy wykazują, iż żadne dostępne dane empiryczne nie potwierdzają socjobiologicznej koncepcji oddziaływania genów i kultury; skutkiem tego trzeba byłoby odwoływać się do wysoce sztucznych założeń dodatkowych, aby koncepcję tę dało się obronić39 ${ }^{39}$. W sumie więc radykalna socjobiologia przedstawiana samokrytycznie jako forma naukowej mitologii okazuje się sugestywna w literackiej wersji właściwej dla mitów a równocześnie trudna do utrzymania w ścisłych sformułowaniach podatnych na testowanie empiryczne.

\section{DYLEMATY SOCJOBIOLOGII}

Socjobiologia jest dyscypliną bardzo młodą i dlatego należy liczyć się z możliwością jej głębokich przekształceń. Podobnie jak to miało miejsce w przypadku marksizmu czy teorii Freuda, krytyczny rozwój badań może prowadzić do odejścia od pierwotnych uproszczeń i radykalnych tez zawartych w krytyce religii. Jakie pozytywne elementy socjobiologii można by wtedy zaakceptować z punktu widzenia myśli chrześcijańskiej? Sądzę, iż jeśli odrzuci się profetyczne deklaracje socjobiologii, i nie ograniczy jej oceny do propozycji zawartych w literackich impresjach Wilsona i Ruse'a, otrzymujemy wiele pozytywnych twierdzeń, które zasługują na uwagę z punktu widzenia myśli chrześcijańskiej.

1. Na przekór teoriom, które głosiły iż religia zrodziła się z lęku człowieka przed nieznanymi siłami przyrody albo została narzucona w interesach kleru, socjobiologia uznaje dążenia religijne ludzkości za trwały element natury ludzkiej. Człowiek jawi się więc jako animal religiosum nie tylko na poziomie psychicznych zainteresowań czy intelektualnych interpretacji, lecz już na poziomie czysto biologicznym dzięki wszczepionemu w nasz genotyp ukierunkowaniu ku transcendentnej Bożej rzeczywistości. Ujęcie takie pozostaje szczególnie bliskie tym współczesnym przedstawicielom epistemologii kalwińskiej, którzy twierdzą, iż przekonanie o istnieniu Boga należy do podstawowych przekonań (proprely basic) intuicyjnie oczywistych dla naszego gatunku ${ }^{40}$.

Teza o genetycznym uwarunkowaniu religii pozostaje całkowicie niezależna od prawdziwości tezy o istnieniu Boga. Ostatniej kwestii nie daje się rozstrzygnąć na poziomie badań genetyki. Osobnym zagadnieniem pozostaje fakt, iż niektóre z propozycji Wilsona i Dawkinsa dotyczące genetycznej interpretacji altruizmu spotkały się z zasadniczą krytyką prowadzoną właśnie z pozycji genetyki ${ }^{41}$. Niezależnie od wyników tej krytyki, oczywista pozostaje do-

${ }^{39}$ Zob. np. J. M. S mith, N. W a r r e n, Models of Cultural and Genetic Change, „Evolution” 36 : 1982 s. 620; E. Le a ch, Biology and Social Science: Wedding or Rape?, „Nature” $291: 1981$ s. 267; P. Me d a wa r, Stretch Genes" "The New York Review of Books" 1981, 16 July.

40 Zob. np. W. P. Als to n, 'Plantinga's Epistemology of Religious Belief, [w:] Alvin Plantin$g a$, ed. J. E. Tom berlin, P. van Inwege n, Reidel 1985, s. 289.

41 ,The inferences from selfish alleles to selfish genes, and from selfish genes to selfish organism are extremely problematic" (D. L. Hull, jw., s. 85; por. tegoż autora: Individuality and Selection, „Ann. Rev. of Ecology and Systematics” 11: 1980 s. 311). 
wolność Wilsonowskiej afirmacji ateizmu. Genetyczne podłoże religii nie implikuje iluzorycznego charakteru jej twierdzeń, podobnie jak genetyczne uwarunkowanie naszego przeżycia przyjaźni lub miłości nie oznacza, iż przeżycia te stanowią wędrówkę w świat iluzji. Genetyczne uwarunkowania matematyki nie upoważniają do kwestionowania prawdziwości tabliczki mnożenia; w sumie więc ateizm radykalnej socjobiologii pozostaje całkowicie niezależny od jej pozostałych tez. Wyrazem arbitralnej prywatnej filozofii Wilsona pozostaje teza, iż moc religii zostanie „raz na zawsze zniszczona”, jeśli określi się biologiczne podłoże jej rozwoju związane z ewolucją mózgu ${ }^{42}$. Za godny uwagi należy uznać fakt, iż sam Ruse nie akceptuje równie uproszczonej wersji ateizmu. Opowiada się on, jak czyni to często w wykładzie swej filozofii, za jakąś niesprecyzowaną koncepcją Boga deistów $w^{43}$. Jej uściślenie jest tym trudniejsze, że w rozmytej epistemologii Ruse'a nie widać granicy między ontologią a naukami szczegółowymi, gdyż jak zapewnia on „filozofia jest 'meta-fizyką' — rozmową o fizyce - i odwrotnie nauka jest filozofią przyrody" 44 . Po podobnym „wymieszaniu" perspektyw poznawczych nie należy oczekiwać precyzji w odpowiedziach na podstawowe pytania metafizyki. Nie ma jednak obiektywnych powodów, by wszyscy socjobiologowie mieli praktykować styl analiz właściwy dla Wilsona i Ruse'a.

2. Na przekór ujęciom głoszącym alienujący charakter religii czy jej zachowawcze funkcje społeczne, socjobiologia uznaje pozytywną rolę religii na poziomie zarówno integracji indywidualnej osobowości jak i życia społecznego. Niemożliwe do merytorycznego uzasadnienia pozostaje natomiast twierdzenie, iż biologiczna korzyść gatunku ludzkiego stanowi najwyższy cel przekonań religijnych. Status takiego twierdzenia pod wieloma względami przypomina status teologicznego wariantu Zasady Antropicznej, który glosi, iż powstanie i zachowanie życia stanowi najwyższy cel ewolucji kosmicznej. Podczas gdy w nauce przyznaje się wartość eksplanatywną słabszym wariantom Zasady Antropicznej, wariant teleologiczny uważany jest za wytwór antropomorfizującej wyobraźni, pozbawiony merytorycznego uzasadnienia. Podobną opinię należy skierować w stronę tezy głoszącej, iż kultura, nauka i religia nie są niczym więcej jak tylko formami ewolucyjnego dostosowania do prowadzonej walki o byt.

3. Teza o genetycznym uwarunkowaniu pewnych wartościowań, norm etycznych i postaw egzystencjalnych koresponduje ze stanowiskiem uznającym istnienie prawa naturalnego czy powszechnej natury ludzkiej. Doniosłość tej konstatacji łagodzona jest natomiast przez fakt, iż u samego Wilsona można w tekstach powstałych w okresie 10 lat, znaleźć krańcowo różne, nierzadko

\footnotetext{
42 O naturze..., s. 240.

43 Taking Darwin Seriously, s. 191, 201, 254.

${ }^{44}$ Tamże, s. 273.
} 
wzajemnie niespójne, koncepcje natury ludzkiej. Kiedy broni się on przed zarzutem rasizmu, akcentuje uniwersalne elementy tej natury. Gdy usiłuje krytykować stanowisko teizmu chrześcijańskiego, kładzie nacisk na to, iż współoddziaływanie genów i kultury może prowadzić do zmian elementów uważanych wcześniej za powszechniki niezależne od kultur i czasu.

Charakterystyczny styl analiz Wilsona pojawia się znowu, gdy osobiste refleksje na temat natury ludzkiej przedstawia on jako wnioski socjobiologii. Tak np. broni on tezy, iż „homoseksualizm jest rzeczą normalną w sensie biologicznym" 45 , ubolewając przy tym, iż ,większość psychiatrów uważa homoseksualizm za rodzaj choroby" 46 . Wilson nie precyzuje, dlaczego jego opinię należy cenić wyżej niż opinię innych psychiatrów, zaś z przytoczonej przezeń argumentacji wynika jedynie wątpliwy merytorycznie wniosek, iż każde zachowanie przynoszące szeroko rozumiane korzyści praktykującej je grupie należy uznać za normalne.

Aby uniknąć nieporozumień co do Wilsonowskiej koncepcji natury ludzkiej, warto odnotować jeszcze jedną hipotezę, w której przedstawia on homoseksualizm jako uwarunkowaną genetycznie formę przekazu „rzadkich altruistycznych impulsów ludzkości”47. Perspektywa aksjologiczna, w której matka Teresa zostaje uznana za egoistkę, natomiast homoseksualiści występują w roli nauczycieli altruizmu, nie wymaga komentarzy. Podobna aksjologia nie wynika jednak z podstawowych tez socjobiologii. Ta ostatnia uznaje istnienie zasadniczych trudności przy próbach narzucania radykalnych zmian naturze ludzkiej i tym samym przeciwstawia się zarówno relatywizmom kulturowym jak i filozofiom traktującym człowieka jako wynik określonych uwarunkowań społecznych.

Czynnikiem, który przyczynia się w dużym stopniu do konfliktu między socjobiologiczną a religijną wizją rzeczywistości, jest z jednej strony brak ostro określonego kryterium prawdy w socjobiologii, z drugiej zaś bezpodstawne łączenie redukcjonizmu ontologicznego $\mathrm{z}$ wymaganym $\mathrm{w}$ nauce redukcjonizmem metodologicznym. Gdyby z tekstów radykalnej socjobiologii usunąć niejasności i niekonsekwencje związane z tymi dwoma brakami, zniknęłoby z niej wiele arbitralnych i kontrowersyjnych filozoficznie tez, ale równocześnie zmiejszyłaby się psychologiczna atrakcyjność znamienna dla wszystkich koncepcji proponujących proste thumaczenia skomplikowanych zjawisk.

Mimo iż Ruse złagodził niektóre $\mathrm{z}$ radykalnych tez Wilsona i opowiedział się jednoznacznie za istnieniem wolnych wyborów moralnych u człowieka ${ }^{48}$,

45 O naturze..., s. 183.

46 Tamże, s. 181.

47 Tamże, s. 183.

48 Omawiając tę właśnie problematykę, Wilson doprowadzał do wirtuozerii połączenie retorycznego wywodu z mglistością wieloznacznych sformulowań. U Ruse’a otrzymujemy natomiast jednoznaczne w swej wymowie konstatacje, gdy przyznaje on: „Morality gives us standards which 
w swej ewolucyjnej epistemologii nie odpowiedział bynajmniej na pytanie, co stanowi ostateczne kryterium prawdy. Niektóre z jego tekstów jednoznacznie sugerują, że suma kątów w geometrii Euklidesa równa się $180^{\circ}$, zaś $2+2=4$ jedynie dlatego, iż twierdzenia te są przydatnie w ewolucyjnej walce o byt. Ten brak przemyślanej do końca epistemologii sprawia, iż także wierzenia religijne ujmuje się wyłącznie w aspekcie ich ewolucyjnej przydatności, unikając trudnych pytań o transcendentny sens tych wierzeń.

Podobne problemy łączą się $\mathrm{z}$ akceptacją redukcjonizmu filozoficznego w celu otrzymania prostszej wizji rzeczywistości. Należy zauważyć, iż doktryna redukcjonizmu ontologicznego odegrała co najmniej dwuznaczną rolę w procesie rozwoju nauki. Po przyjęciu prostych tez tej doktryny XIX-wieczni przedstawiciele mechanicyzmu deklarowali bliską już możliwość wyjaśnienia pojęcia prawdy czy piękna w kategoriach mechaniki Newtonowskiej. Głosząc redukcjonizm Ernst Mach, którego filozofię nauki wspomina z głębokim uznaniem M. Ruse, kategorycznie odrzucał zarówno Einsteinowską teorię względności, jak i tezę o istnieniu atomów. Fizyka po rewolucji Einsteina-Plancka niszczyła prostotę redukcjonistycznego obrazu świata, dlatego też Mach odrzucał ją kategorycznie w imię prostoty obrazu. Swoiste curiosum stanowi wykład Machowskiej mechaniki wydany już po powstaniu ogólnej teorii względności, w którym to wykładzie systematycznie uważa się atomy za metafizyczne produkty pozbawione realnych odpowiedników w przyrodzie.

Redukcjonizm metodologiczny przyjęty jako technika badawcza prowadzi do heurystycznie wartościowych programów badań. Redukcjonizm ontologiczny, sprowadzający całe bogactwo rzeczywistości do niewielkiego zbioru determinant, niejednokrotnie już prowadził do dogmatyzmu interpretacyjnego, w którym - w imię prostoty profetycznych wizji - usiłowano podważać niekwestionowalne fakty. Stanowi on niewątpliwie atrakcyjną filozofię dla wszystkich dyscyplin w początkowym stadium ich rozwoju. Jego klasycznym przejawem pozostaje interpretacyjny nic-więcyzm (nothing-butism), w którym bez troski o merytoryczne uzasadnienie deklaruje się, iż określona klasa zjawisk stanowi nic wi ęce j niż pochodną innej klasy determinant. Ten właśnie nicwięcyzm wprowadzono w próbach redukowania zjawisk religijnych do determinant genetycznych. Krytycy podobnego ujęcia odwołują się do analogii z ludzkim przeżywaniem miłości. Przeżycie to posiada określone podłoże w postaci reakcji chemicznych zachodzących w naszym organizmie. Nie wynika jednak z tego, iż całe bogactwo ludzkiego przeżycia miłości można przełożyć na język

we feel the demand to follow; but there is nothing within or without us that alone determines that we must or must not follow these moral demands. We can respond to morality, and depending on circumstances we may or may not follow it. This is our freedom " (The Evolution..., s. 261). Nowsze ujęcie tej problematyki przedstawił Ruse w: Darwinism and Determinism, „Zygon” 22 : 1987 s. 419. 
chemii. Sama próba takiego przekładu byłaby równie groteskowa, jak wiele innych prób obrony redukcjonizmu ontologicznego.

Mimo iż sam Wilson uważa dziedzinę socjobiologicznych badań nad religią za najbardziej ekscytujący obszar stwarzający okazję przekształcenia socjobiologii „w prawdziwie oryginalną dyscyplinę teoretyczną"49, jego optymizm oceniany jest sceptycznie przez tych badaczy, którzy nie identyfikują refleksji teoretycznej $\mathrm{z}$ tworzeniem wizjonerskich interpretacji niepodatnych na testy empiryczne. Testowanie w dziedzinie genetyki można względnie łatwo prowadzić na groszku lub muszkach Drosophilla. Sytuacja ulega radykalnej zmianie, kiedy wchodzi w grę testowanie związków między kulturą a genotypem człowieka. Socjobiologia odrzuca najbardziej naiwne koncepcje, w których np. socjalistyczne zasady organizacji społeczeństwa przekazywane będą n atych mias t drogą genetyczną. W swoistym nowym millenaryzmie głosi się, iż trzeba około 1000 lat, aby zmiany zachodzące w kulturowym środowisku człowieka znalazły swój genetyczny odpowiednik ${ }^{50}$. Postulat ten zdaje się posiadać falsyfikator w systemie kast występujących w Indiach. Mimo iż system ten utrzymuje się przez okres dłuższy niż przez 1000 lat, nie zauważono żadnych genetycznych różnic odpowiadających zróżnicowaniom między poszczególnymi kastami.

Ewentualne próby empirycznego testowania tezy o genetycznych uwarunkowaniach kultury dostarczą zapewne tych samych kontrowersji metodologicznych, które towarzyszyły w przeszłości pytaniom o genetyczne uwarunkowania ilorazu inteligencji. Nie tylko w różnych ośrodkach badawczych uzyskiwano krańcowo różne wyniki, ale uważane za najbardziej miarodajne rezultaty Cirila Burta, nazywanego „dziekanem psychologów świata”, okazały się wynikiem systematycznego stosowania oszustw. Rezultaty te potwierdzały tezę o wrodzonym charakterze inteligencji. Odkrycie, iż zostały one wymyślone bez przeprowadzania jakichkolwiek badań empirycznych, stało się możliwe dzięki temu, iż w trzech niezależnych programach badawczych miały one dawać ten sam współczynnik korelacji z dokładnością do trzeciej cyfry po przecinku. Statystycznie nieprawdopodobna zgodność teorii z doświadczeniem stworzyła okazję do odkrycia fałszerstwa ${ }^{51}$.

Krytyczna ocena predykcji formułowanych w konkretnych modelach socjobiologii nie przesądza możliwości konstrukcji odmiennych modeli. Zamiast wiązać większe nadzieje $\mathrm{z}$ wynikami ich testowania empirycznego, bardziej uzasadnione wydaje się uwzględnienie tych analogii z dziedziny historiografii,

49 O naturze..., s. 215.

${ }^{50}$ Zob. sceptyczne uwagi J. Goulda na ten temat w: An Urchin in the Storm, s. 39 n., oraz przytaczaną tam sarkastyczną uwagę Kitchera: „Zasada tysiąca lat stanowi twierdzenie o wzajemnej ewolucji genetyczno-kulturowej wówczas, gdy odnosimy je do ewolucji hipotetycznych osobników o nadzwyczajnej głupocie".

51 Przypadek ten opisuja W. B road i N. Wa d e w pracy: Betrayers of the Truth: Fraud and Deceit in the Halls of Science, New York 1982, s. 203 - 210. 
które ukazują, jak głębokim zmianom mogą ulegać teorie przyrodnicze zachowując niezmienny twardy rdzeń podstawowych twierdzeń. Uwzględnienie wcześniejszych analogii stwarza szansę uwolnienia socjobiologii z ideologicznego komentarza, w którym deklaruje się ikonoklastyczny charakter ich twierdzeń nie zadając sobie trudu uzasadniania tez o podstawowej doniosłości.

\section{SOCJOBIOLOGIA EWOLUCJI A EWOLUCJA SOCJOBIOLOGII}

Wyjątkowość epistemologicznego statusu socjobiologii przejawia się w tym, iż jest ona dyscypliną o wyraźnie totalizujących dążeniach. Liczne deklaracje sympatyków radykalnej socjobiologii zapewniają, iż przyszły rozwój wiedzy doprowadzi do tego, że reprezentowana przez nich dyscyplina będzie jedyną i uniwersalną dyscypliną naukową, gdyż zarówno nauki przyrodnicze jak i humanistyczne zostaną wchłonięte przez socjobiologię. M. Ruse dodaje nawet, iż taka właśnie wizja socjobiologii, która demistyfikuje zarówno genetyczne źródła religii czy etyki, jak i ewolucyjne podłoże filozofii i matematyki, stanowi proste wyciągnięcie wniosków z teorii Darwina. „W 125 lat po pierwszym wydaniu On the Origin of Species - konkluduje on w zakończeniu swej książki - nadszedł z pewnością czas, aby traktować Darwina serio"52.

Ostatnia wypowiedź zdaje się sugerować, iż darwinizm nie był dotychczas traktowany serio oraz że monopol na takie właśnie traktowanie posiadają sympatycy radykalnych tez Wilsona. Ci ostatni chętnie odwołują się do analogii $\mathrm{z}$ teorią Darwina, porównując protesty, jakie w XIX wieku wywoływał darwinizm, ze współczesną krytyką socjobiologii. Znamienne świadectwo tego właśnie podejścia stanowiło zaproszenie Davida L. Hulla, by do poświęconego socjobiologii tomu Sociobiology and Human Nature przygotował artykuł sugerujący, iż współcześni krytycy ujęć Wilsona reprezentują ten sam ciasny fanatyzm, który 100 lat wcześniej reprezentowali krytycy Darwina ${ }^{53}$.

Przyjmując zaproszenie Hull zmienił sugerowane mu podejście. Zajął się on nie tylko opozycją przeciw darwinizmowi, lecz również opozycją przeciw frenologii Galla. Niemiecki lekarz Franz J. Gall (1758 - 1828) był nie mniejszym autorytetem w dziedzinie biologii mózgu niż Edward Wilson w dziedzinie entomologii. Źródłem głębokich kontrowersji stała się głoszona przez niego teza, iż ludzkie zdolności intelektualne są determinowane przez kształt czaszki. Teza ta, uważana obecnie za jawny absurd, uważana była przez długi czas za ekspresję ambitnego programu badań, w którym określa się fizjologiczne determinanty procesów myślowych czy akceptowanych postaw etycznych. Do jej gorących zwolenników należeli m. in. Balzac, Comte, Mark Twain, Her-

52 Taking Darwin Seriously..., s. 279.

53 D. L. Hull, Scientific Bandwagon or Travelling Medicine Show?, [w:] Sociobiology and Human Nature, s. 136. 
bert Spencer. Mimo filozoficznej atrakcyjności i słów uznania, jakich nie szczędzili jej autorzy tak znani jak Paul Broca czy Karol Marks, frenologia okazała się ostatecznie produktem fantazji pozbawionym empirycznych konfirmacji.

Jakie czynniki zadecydowały, iż krytykowana przez długi czas teoria Darwina umacniała swą pozycję $\mathrm{z}$ rozwojem badań, natomiast przyjmowana w niektórych kręgach z entuzjazmem frenologia jest obecnie zaliczana do pseudonauki? D. Hull wymienia kilka takich czynników. Osobiście skłonny byłbym sądzić, iż na popularność frenologii wpłynął w dużym stopniu jej zdroworozsądkowy redukcjonizm deklarujący prostą wizję świata, w której zgodnie $\mathrm{z}$ ontologią materializmu zjawiska psychiczno-duchowe zostają zredukowane do obserwowalnych determinant. Wyznawany przez Galla materializm i redukcjonizm przyciągał szerokie rzesze sympatyków szukających prostych tłumaczeń dla skomplikowanych problemów. Wybrane selektywnie przykłady korelacji między kształtem czaszki a postawą intelektualną miały dostarczać sugestywnego potwierdzenia głoszonej tezy. Szukając takich potwierdzeń Gall eliminował ze swej dokumentacji przykłady niewygodne. Już jednak w kilka lat po przedstawieniu jego teorii specjalna komisja powołana przez Institut de France orzekła w 1808 r. iż dostępne dane empiryczne nie upoważniają do obrony przedstawionych tez.

Istnieją jeszcze dodatkowe czynniki, które pozwalają wyjaśnić, dlaczego z upływem badań teoria Galla uległa odrzuceniu zaś obrazoburcza teoria Darwina umocniła swą pozycję. Otóż Darwinowska teoria doboru naturalnego była teorią par excellence przyrodniczą. Darwin redukował w niej do minimum pozanaukowe wtręty o charakterze metafizycznym czy teologiçnym. Próby filozoficznej, religijnej czy antropologicznej krytyki tej teorii były wprowadzane przez jej oponentów, którzy z reguły dodawali arbitralny komentarz metafizyczny do tez przyrodniczych neutralnych w swym wydźwięku metafizycznym. Rozwój badań prowadził zarówno do zdobycia empirycznych konfirmacji teorii, jak i do odkrycia dowolności metafizycznych komentarzy wprowadzanych przez jej krytyków.

W przypadku socjobiologii istniejąca baza empiryczna okazuje się nadzwyczaj szczupła. Kilka przytaczanych z predylekcją typów zjawisk, wśród których argument koronny ma dostarczać fakt istnienia środowiskowych uwarunkowań kazirodztwa, można tłumaczyć na wiele różnych sposobów bez potrzeby uciekania się do założeń równie mocnych jak te, które znajdujemy w klasycznych pracach Wilsona. Sam Wilson dostrzegł ten fakt wprowadzając w kolejnych publikacjach istotne retusze do wcześniejszych mocnych tez. Pozbawione jakichkolwiek empirycznych potwierdzeń pozostają jednak niezmiennie praktykowane przezeń generalizacje, w których stwierdza się np. iż „celem ofiary 
jest wyniesienie jednej grupy ludzkiej ponad inną" ${ }^{44}$ zaś „świętość jest nie tyle hypertrofią ludzkiego altruizmu, co jego skostnieniem" 55 . Podobnych konstatacji można dowolnie długo bronić przed falsyfikacją rezerwując dla siebie uprawnienia demistyfikatora i twierdząc np., iż składający ofiarę życia o. Maksymilian Kolbe chciał jedynie przez swą ofiarę wynieść popularność franciszkanów nad inne zakony. Sympatycy demistyfikacyjnych praktyk nie są jednak zwolnieni z obowiązku uzasadnienia demaskatorskich tez, jeśli chcą, by ich interpretacje zaliczać do nauki, nie zaś do jej karykaturalnych namiastek.

Zamiast racjonalnych uzasadnień Wilson i Lumsden przytaczają swe wyznanie wiary $w$ redukcjonizm oraz akcentują prostotę redukcjonistycznej wizji świata. Krytyków atakujących uproszczenia takiego ujęcia informują oni: „obecnie nie ma żadnych dowodów naukowych, że emergencji podstawowych cech jakiegoś potomka Karola Wielkiego lub Quatrocento nie można by wyjaśnić po odniesieniu do rozwoju historycznego jakiejś rozwiniętej teorii współoddziaływania genów i kultury" 56 . Po zapewnieniu, iż podobna postać zgenetyzowanego heglizmu jest jeszcze kwestią odległej przyszłości, Wilson i Lumsden zwracają uwagę, iż już obecnie możemy dokładnie określać kierunek ewolucji systemów przy badaniu takich procesów jak ruch pocisku lub rozwój epidemii. Przy założeniu materialistycznego monizmu, w którym głosi się bliski klasycznemu mechanicyzmowi redukcjonizm, autorzy ci wprowadzają optymistyczną zapowiedź, iż ,nie ma żadnych powodów, by sądzić, że myśli i kultury człowieka nie da się badać” przy pomocy tych samych wzorców, które służą do badania ruchu pocisków ${ }^{57}$.

Podobne deklaracje wyrażające interpretacyjne preferencje autorów są wprowadzane systematycznie zamiast racjonalnych uzasadnień. U ich podstaw znajduje się redukcjonistyczna teza, która głosi: „W społeczeństwie, kulturze czy religii nie ma niczego, co nie istniałoby wcześniej w organizmie i jego genotypie". Ta właśnie teza napotyka radykalne sprzeciwy antropologów, którzy uznają za bezpodstawne próby totalnego biologizowania zjawisk społecznych. Twierdząc, iż biologia pozwala wyjaśnić tylko niektóre z tych zjawisk, powtarzają oni za Marshallem Sahlinsem: „biologia, stanowiąc absolutnie konieczny warunek kultury, jest jednak również warunkiem absolutnie niewystarczającym. Jest ona absolutnie pozbawiona uprawnień do określenia kulturowych cech ludzkiego zachowania czy ich zmienności przy przechodzeniu od jednej ludzkiej grupy do drugiej”58. „Idea stałej korespondencji między wrodzonymi dyspozycjami człowieka a jego społecznymi formami stanowi słabe ogniwo,

${ }^{54}$ O naturze..., s. 189.

55 Tamże, s. 206.

56 Promethean Fire, s. 172.

57 Tamże, s. 173.

${ }^{58}$ M. S a hlins, The Use and Abuse of Biology, University of Michigan Press 1976, s. XI. 
w istocie nawet pęknięte ogniwo, w łańcuchu socjobiologicznych rozumowań" 59 .

Koncepcja, która miała przynieść radykalnie nową antropologię, jest więc przedmiotem krytyki samych antropologów, którzy nie widzą powodu, by „przestarzały redukcjonizm" 60 ontologiczny cenić wyżej niż znane fakty empiryczne. W tej sytuacji wyrazem metodologicznego krytycyzmu byłoby zrezygnowanie z tych tez, które wyrażają jedynie metafizyczne czy estetyczne sympatie twórców biologii, lecz ani nie prowadzą do predykcji empirycznych, ani też nie tłumaczą całego zespołu dostępnych danych. Zmierzające w tym właśnie kierunku próby badań podjęli L. L. Cavalli-Sforza i M. W. Feldman ${ }^{61}$. W ich ujęciu nie próbuje się apriorycznie przesądzać wyników badań ani też narzucać arbitralnych ograniczeń na przebieg procesów ewolucyjnych, lecz tylko konstruuje się alternatywne modele, które po poddaniu testom empirycznym pozwolą wykluczyć pewne warianty ewolucji kulturowej oraz wprowadzić dodatkowe uściślenia w konkurencyjnych modelach. Ten właśnie sposób badania interakcji między genotypem a kulturą stwarza nadzieję przekształcenia socjobiologii w dyscyplinę naukową, w której ogólnie przyjęte zasady krytycyzmu metodologicznego cenione są wyżej od wszystko tłumaczących niesprawdzalnych wizji. Nie można, oczywiście, wykluczyć, iż rozwijana w ten sposób socjobiologia ograniczy się do zbioru niekontrowersyjnych truizmów, z których wynika jedynie, iż dyscyplina ta okazuje się „przygniatająco nieistotna dla obecnej kondycji ludzkiej"62. Możliwość taka stanowi jednak mimo wszystko mniejsze zagrożenie dla nauki niż rozwijanie quasi-naukowej mitologii traktowanej jako źródło najgłębszych prawd.

Sam Wilson na kartach Biophilii usiłował usprawiedliwiać własne podejście metodologiczne, twierdząc iż w genezie rewolucji naukowych odważne ekstrapolacje odegrały większą rolę niż analityczny krytycyzm. Warto jednak zauważyć, iż rewolucyjne ekstrapolacje Galileusza, Newtona czy Darwina posiadały niepustą dziedzinę ważnych falsyfikatorów, które pozwalały odróżnić nowatorskie teorie od literackich wizji. W propozycjach radykalnej socjobiologii walory literackie tekstów zdecydowanie górują nad elementarnymi zasadami metodologii. Dominacja retoryki i troski o prostotę wizji nad elementarnym krytycyzmem metodycznym osiąga taki stopień, iż Ruse nie waha się nawet wyrazić ubolewania, że proste związki między genami a kulturą ulegają skomplikowaniu na wyższych stopniach ewolucyjnego rozwoju ${ }^{63}$.

59 Tamże, s. 7.

60 Określenie J. Goulda: An Urchin..., s. 118.

61 Towards a Theory of Cultural Evolution, „Interdisciplinary Science Review” 3: 1979; Cultural Transmission and Evolution, Harvard University Press 1981.

62 G. W als, The Human Condition, [w:] Sociobiology and Human Nature, s. 277.

63 "In the case of organisms remote from man, like insects, one can be fairly certain that virtually all of their „culture" is genetic. Un f o r t u n a t e ly, as one gets closer to man, the possibilities of nongenetic culture rises" (M. R u s e, Sociobiology: A Philosophical Analysis, w: The Sociobiology Debate, ed. A. L. Caplan, New York 1978, 277). 
Mimo zapewnień Ruse'a, iż socjobiologia stanowi jedynie konsekwentną kontynuację darwinizmu, można łatwo wskazać istotne różnice między Darwinowską metodyczną ostrożnością a Wilsonowską sympatią do bezpodstawnych uogólnień. Dysponując obszerną dokumentacją dotyczącą zarówno małp jak i człowieka, Darwin nie zdecydował się w The Origin of Species ekstrapolować praw doboru naturalnego na poziom ludzki i potrzebował dodatkowych 12 lat przemyśleń, by wprowadzić taką ekstrapolację w The Descent of Man. W przeciwstawieniu do niego Wilson, posiadając kompetencje jako badacz owadów, nie wahał się bez uzasadnienia, w imię przyjętego jako artykuł wiary redukcjonizmu ontologicznego, ekstrapolować prawidłowości występujące u mrówek na całą rzeczywistość ludzkiej kultury ze znamiennym dla niej altruizmem etycznym, teoretyczną refleksją naukową, wierzeniami religijnymi.

W ciągu niespełna 15 lat, jakie minęly od pierwszego wydania Sociobiology: the New Synthesis socjobiologiczna próba syntezy została poddana głębokim rewizjom. Usunięto z niej większość dwuznacznych sformułowań, które dostarczały podstawy do oskarżeń o rasizm, konserwatyzm społeczny czy znamienne dla obozu prawicy poglądy polityczne ${ }^{64}$. Niektóre z przedstawionych ostatnio propozycji stwarzają szansę jej dalszego przekształcenia, przez co na miejsce sugestywnych metafor i niesprawdzalnych ogólników wprowadzi się testowalne modele matematyczne. Te ostatnie nie pozwolą wprawdzie na matematyzację ludzkich uczuć czy wprowadzenie sformalizowanych wskaźników altruizmu ${ }^{65}$. Mogą jednak wpłynąć na odkrycie ważnych prawidłowości w tych dziedzinach naszej kultury, które nie wymykają się matematycznemu sformułowaniu czy testom empirycznym. Sugerowana zmiana perspektywy poznawczej może przekształcić socjobiologię profetycznych wizji w dyscyplinę empiryczną. Przedstawiciele tej ostatniej nie będą już deklarować, iż przebadanie ludzkiego genotypu pozwala na określenie podzielanych wierzeń religijnych ${ }^{66}$, rozwiną natomiast programy badawcze umożliwiające testowanie tezy, która głosi: wszystkie fenotypy, w każdym stadium ontogenezy, stanowią wynik oddziaływania genotypu $\mathrm{z}$ otoczeniem ${ }^{67}$.

Głębokie różnice w socjobiologicznym tłumaczeniu genezy religii są widoczne, gdy porównuje się teksty Wilsona, zawierające zgenetyzowany wariant socjologizmu Durkheima ${ }^{68}$, z analitycznymi opracowaniami, w których usiłuje

${ }^{64}$ Przez odwołanie się do postaw kulturowych uwarunkowanych genetycznie, a oddziedziczonych przez nas po zwierzęcych praprzodkach, usiłowano usprawiedliwiać $\mathrm{m}$. in. istnienie wojen, nierówności społecznych, niektórych form nepotyzmu.

65 J.S. Alper i R. V. Lan ge w swej krytyce Genes, Mind, and Culture wyrażają zasadnicze wątpliwości, czy możliwe jest zastosowanie niebanalnych technik matematycznych do opisu związków między biologią a kulturą; zob. Lumsden-Wilson Theory of Gene-Culture Coevolution, „Proc. of the Nation. Ac. of Sc.”, $27: 1981$ s. 3976.

66 Por. D. P. B a r a s h, Evolution as a Paradigm for Behavior, [w:] Sociobiology and Human Nature, s. 29.

${ }^{67}$ Tamże, s. 23.

68 Zob. np. E. O. Wils o n, The Relation of Science to Theology, „Zygon” $15: 1980$ s. 425. 
się określać biologiczne uwarunkowania niektórych zakazów religijnych. Nie budzą oporów ${ }^{69} \mathrm{np}$. tłumaczenia, w których Marvin Harris wykazuje, iż praktykowany w hinduizmie kult krów lub przyjmowany w judaizmie i islamie zakaz spożywania wieprzowiny można wytłumaczyć czynnikami biologicznymi. Niewątpliwie w warunkach głodu w Indiach zakazy religijne chronią przed całkowitym wyniszczeniem hodowli i — w kategoriach sięgających dalej niż lokaIna klęska głodu - ułatwiają ewolucyjne przetrwanie ${ }^{70}$. Kontrowersyjny pozostaje tylko problem, czy ten fakt wzajemnego powiązania czynników religijnych i biologicznych, kulturowych i środowiskowych, posiada jakiekolwiek związki z genetyką. Brak argumentów za istnieniem takich związków skłania do sceptycznej oceny prób konfirmowania socjobiologii przy pomocy argumentacji przytaczanej przez Harrisa.

Podsumowując dotychczasowe analizy można więc stwierdzić, iż socjobiologiczna teoria religii pozostaje merytorycznie neutralna w stosunku do kwestii prawdziwości wierzeń religijnych. Na pytanie o prawdziwość tych wierzeń usiłował udzielić negatywnej odpowiedzi E. O. Wilson. Jeśli jednak jego odpowiedź ma być traktowana jako hipoteza naukowa, należy zastosować do niej kryteria oceny stosowane powszechnie do hipotez przyrodniczych. Odniesienie takich kryteriów pozwala stwierdzić, iż socjobiologiczna krytyka religii przez Wilsona stanowi wynik jego wcześniejszych zdeklarowań ontologicznych, które są wynikiem przyjęcia pozanaukowych zasad określających zakres i sposób tłumaczenia znanych zjawisk. W interpretacyjnych preferencjach Wilsona widoczny jest wpływ XIX-wiecznej metodologii, która w fizyce uległa zdyskredytowaniu wraz z nadejściem rewolucji Einsteina-Plancka, a która pozostaje niezmiennie atrakcyjna dla pewnych biologów. O tym, jak dużą rolę w jej wyborze odgrywają uprzednie preferencje filozoficzne, wymownie świadczy przykład Richarda Dawkinsa i Johna Duranta. Autor The Selfish Gene, uważany przez Wilsona za ostateczny autorytet w interpretacjach ukazujących genetyczne podłoże altruizmu, odszedł od chrześcijaństwa podczas studiów w Oxfordzie i przyjął ewolucję jako ostateczny czynnik kierujący rozwojem przyrody. Jego kolega ze studiów, John Durant, podzielając w pełni przyrodnicze poglądy Dawkinsa wypracował w tym samym okresie wizję immanentnego Boga, który przejawia Swą obecność w prawach przyrody. Te same przesłanki przyrodnicze posłużyły za podstawę wypracowania krańcowo różnych filozofii. Być może ta odmienność filozoficznych interpretacji wprowadzanych dla tych samych danych empirycznych dostarcza kolejnego argumentu za tym, iż przyjmowane przez nas poglądy filozoficzne nie są wynikiem uwarunkowań genetycznych.

${ }^{69}$ Por. W. H. A u s t in, Evolutionary Explanations of Religion and Morality: Explaining Religion Away?, [w:] Evolution and Creation, ed. E. Mc Mull in, Notre Dame 1985, s. 264 n.

${ }^{70}$ M. Harris, Cows, Pigs, Wars, and Witches, New York 1978, s. 6-38. 


\section{THE GENETIC BASIS OF RELIGION IN RADICAL SOCIOBIOLOGY}

\section{Sum mary}

The paper deals with epistemological and ontological presuppositions underlying sociobiology in its most radical version developed by E. O. Wilson, M. Ruse and C. J. Lumsden. Sociobiologists are far from being a uniform group with respect to their metaphysical views. Authors as remote as Hume and Plato, Hegel and Kant are referred to as authorites in philosophical comments to sociobiological analysis of human culture. Many radical interpretations proposed in the language of analogies and metaphors by Wilson were later either made more precise by his colleagues or moderated by Wilson himself. Despite the revisions introduced, an invariably controversial issue remains ontological reductionism according to which the content of human culture, religious beliefs and mathematical theorems inculded, is to be generated by biological determinants.

On the level of epistemology, this reductionism implies an iconclastic theory of knowledge in which the classic notion of objective truth must be called into question, because "true" is to mean nothing but ,useful in the evolutionary struggle for survival." It is impossible to question that our knowledge can really facilitate our struggle for survival. However, the main problem remains, whether a given fact is true because it is useful for human survival or rather is it valuable in the struggle for survival because it is true. Wilson and Ruse definitely chose the first alternative when they accentuate the role of illusions in our apparently rational convictions. The illusions resulting in new mythology are to be the essential element determining the content of our religious convictions. The human species functions better because of religiously motivated principles of altruism, detachment and self-sacrifice. As a matter of fact, the principles in question are to be nothing but „a shared illusion of the human race”, the illusion ,produced by our genetic code to facilitate our social coexistence".

In this approach of radical sociobiology, human beings with their trust in science and rationality are to be ruled by myth and involved in mythopeietic activities. The myth assumes different forms in political-ideological debates and in mathematical discussions on the status of the axiom of choice. Its particular expression is found in religion where the sociobiological attempt to explain the "traditional religon by the mechanistic models of evolutionary biology" is to lead "to the crux of the role of mythology in modern life".

If the essence of sociobiological epistemology is restricted to the weak thesis claiming that our knowledge has important genetic determinants, only defenders of the naive theory of the theory of tabula rasa would object to such a standpoint. If, however, the examined epistemology implies a strong determinism in which the so called objective content of our culture is to be determined by genes, its acceptance would result in denial of rational heritage of our species. To notice groundless simplifications of such a procedure, one may refer to comparative analysis and take into consideration the status of corresponding generalizations practiced in 19th century science. There is an obvious analogy between the sociobiological explanation of culture and the optimistic belief of 19th century mechanists in possibility of physical explaining the cultural phenomena. This optimism is evident in bold extrapolations of Ludwig Boltzmann who claimed categorically: „The application of mechanics is extended to the area of what is spiritual. ... Not only human memory is mechanical in nature, but also beauty and truth.... The origin of the concepts of truth and beauty should be explained within the context of mechanics".

When in Boltzmann's declaration one replaces „mechanics” by „sociobiology” and „mechanical" by "genetic", we obtain the strong sociobiological thesis which already became the object of most ardent debates. One should not, nevertheless, expect future replacement of religion by science, because science itself is only an alternative mythology in which one may enjoy the epic of cosmic evolution. The romantic and poetical component of this epic is supposed to be particularly manifest 
in relativistic cosmology where the theory of the big bang and the billions of years of the cosmic evolution play for contemporary man the same psychological role as the Iliad played for ancient Greeks. The privileged position of sociobiology consists thus only in the fact that this discipline „can account for the very origin of mythology by the principle of natural selection acting on the genetically evolving material structure of the human brain".

After denying our intellectual privileges, Ruse treats both mathematical theorems and religious beliefs only in pragmatic-aesthetical categories and, consistently, considers basic principles of theoretical physics, for instance Heisenberg's uncertainty principle, merely as pragmatic devices introduced to bar "the asking of awkward... questions". It is possible to examine empirically the evolution of religious beliefs and to determine the rate of the "growing awareness" of their genetic determinants. One is thus entitled to expect that Wilson will furnish references to empirical investigations that confirm the basic thesis of the evolutionary utility of religion. Instead of the expected references to empirical data, one finds, however, only self-referential arguments in which the „growing awareness" denotes the growing awareness of the champions of sociobiology.

Many objections formulated against sociobiological explanation of the genesis of religious beliefs refer only to Wilson's version of sociobiology and Ruse's variant of sociobiological epistemology. The presented criticism does not justify radical rejection of moderate solutions in which some sociobiological assumptions would be combined with a version of epistemological realism. The same restriction refers to theological ramifications of sociobiology. As Arthur Peacocke rightly emphasizes, the anti-theistic declarations of leading representatives of sociobiology could be easily eliminated and the very emphasis on genetic aspects of evolution would pose no problem for the Christian philosopher who conceives God as the immanent Creator acting in the stuff of the universe. Analysis of possible mutual relationships between the sociobiological and Christian philosophy of nature remains practically impossible unless basic assumptions of sociobiology are precisely formulated. 